\title{
Faktor yang Berhubungan dengan Beban Caregiver dalam Merawat Keluarga yang Mengalami Stroke
}

\author{
Yolla Nandha Ariska ${ }^{1 *}$, Prita Adisty Handayani' ${ }^{2}$, Elis Hartati \\ ${ }^{1}$ Sekolah Tinggi Ilmu Kesehatan Telogorejo Semarang, Indonesia \\ ${ }^{2}$ Departemen Ilmu Keperawatan Fakultas Kedokteran, Universitas Diponegoro, Semarang, Indonesia
}

yollanandha@gmail.com

\begin{abstract}
Introduction: Stroke is a disease that most often causes disability in the form of paralysis of the limbs, speech disorders, thought processes and other forms of disability. In this condition, stroke patients need caregiver assistance to meet their daily needs. The caregiver faces physical, psychological, social, economic problems in providing care. This study aimed to determine the factors associated with caregiver burden in caring for family members suffering from stroke.

Methods: This was a quantitative study with a cross sectional design. The research instrument used the Zarit Burden Interview questionnaire. The study recruited 56 caregivers as the sample with the inclusion criteria of caregivers aged $\geq 26$ years old, providing care for stroke patient as a main caregiver in at least 3 monthsduration of care. The samples were selected by applying purposive sampling technique, and the data were analyzed by Chi Square test.

Results: The study shows a significant relationshipbetween age $(p=0.009)$, gender $(p=0.001)$, employment status $(p=0.002)$, income $(p=0.000)$, marital status $(p=0.025)$, family relationship $(p=0.011)$, family support $(p=0.000)$ and caregiver burden, however no correlation was identified between education and caregiver burden $(p=0.155)$.

Conclusion: Age, gender, employment status, income, marital status, family relationships and family support are significantly related to the burden of caregivers in caring for stroke family members. Health services are expected to adequately provideinformation for caregivers related to how to care for stroke patients, in order to reduce the caregiver's burden.
\end{abstract}

Keywords: Caregiver Burden, Family, Stroke.

\begin{abstract}
Abstrak
Pendahuluan: Stroke merupakan penyakit yang paling sering menyebabkan kecacatan berupa kelumpuhan anggota gerak, gangguan bicara, proses berfikir dan bentuk kecacatan yang lain. Pada kondisi tersebut pasien stroke memerlukan bantuan caregiver untuk memenuhi kebutuhan seharihari. Caregiver memiliki masalah tekanan fisik, psikologis, sosial, ekonomi pada saat memberikan perawatan. Penelitian ini bertujuan untuk mengetahui faktor-faktor yang berhubungan dengan beban caregiver dalam merawat anggota keluarga yang mengalami stroke.

Metode: Jenis penelitian kuantitatif dengan desain cross sectional. Instrumen penelitian menggunakan kuesioner Zarit Burden Interview. Penelitian ini melibatkan 56 caregiver sebagai sample dengan kriteria inklusi caregiver berusia $\geq 26$ tahun, caregiver utama yang merawat pasien stroke selama minimal 3 bulan. Sample tersebut dipilih dengan menggunakan Teknik purposive sampling, dan data dianalisa dengan menggunakan uji Chi Square.

Hasil: penelitian menunjukan adanya hubungan antarausia $(p=0,009)$, jenis kelamin $(p=0,001)$, status pekerjaan $(\mathrm{p}=0,002)$, penghasilan $(\mathrm{p}=0,000)$, status pernikahan $(\mathrm{p}=0,025)$, hubungan keluarga
\end{abstract}


$(\mathrm{p}=0,011)$, dukungan keluarga $(\mathrm{p}=0,000)$ dengan beban caregiver, namun tidak ditemukan hubungan antara pendidikan dan beban caregiver $(\mathrm{p}=0,155)$.

Kesimpulan: Usia, jenis kelamin, status pekerjaan, penghasilan, status pernikahan, hubungan keluarga dan dukungan keluarga memiliki hubungan yang signfikan dengan beban caregiver dalam merawat anggota keluarga stroke. Pelayanan kesehatan diharapkan dapat memberikan informasi secara adekuat pada caregiver terkait perawatan pasien stroke sehingga dapat mengurangi beban caregiver.

Kata kunci: Beban Caregiver, Keluarga, Stroke.

\section{PENDAHULUAN}

Stroke adalah kelainan pada fungsi otak secara mendadak dan berlangsung lebih dari 24 jam yang disebabkan adanya gangguan suplai darah ke otak. Dalam jaringan otak, kekurangan aliran darah menyebabkan serangkaian reaksi biokimia yang dapat merusak atau mematikan sel-sel otak (Wiwit, 2010).

World Health Organization (WHO) memprediksi bahwa kematian akibat stroke akan meningkat seiring dengan kematian akibat penyakit jantung dan kanker, kurang lebih 6 juta pada tahun 2010 menjadi 8 juta di tahun 2030 (American Heart Association, 2010). Kementerian Kesehatan Republik Indonesia (2018) menyebutkan penyakit tidak menular (PTM) di Indonesia mengalami peningkatan dibandingkan pada tahun 2013, prevalensi stroke meningkat dari $7 \%$ menjadi $10,9 \%$. Data yang diperoleh dari rekam medik RSUD Tugurejo Provinsi Jawa Tengah tanggal 7 Februari 2019 memperlihatkan bahwa pasien rawat jalan dengan stroke pada tahun 2016 berjumlah 729 pasien, 2017 terdapat 842 pasien sedangkan tahun 2018 berjumlah 780 pasien (Rekam Medis RSUD Tugurejo Provinsi Jawa Tengah, 2019).

Stroke merupakan penyakit yang paling sering menyebabkan cacat berupa kelumpuhan anggota gerak, gangguan bicara, proses berpikir, daya ingat dan bentuk kecacatan yang lain sebagai akibat gangguan fungsi otak (Muttaqin, 2011).
Stroke dengan kelumpuhan sebagian atau keseluruhan membutuhkan proses penyembuhan dengan jangka waktu yang cukup lama, sehingga pasien stroke sangat bergantung pada orang-orang di sekitarnya, khususnya keluarga. Keluarga sebagai orang yang sangat dekat dengan pasien stroke, sangat berperan dalam memberikan perawatan lanjutan dan memenuhi kebutuhan perawatan diri pasien. Tugas kesehatan keluarga salah satunya adalah merawat anggota keluarga yang mengalami masalah kesehatan. Apabila salah satu anggota keluarga menderita gangguan kesehatan keluarga yang lain mengemban peran sebagai caregiver (Friedman, Bowden, \& Jones, 2010).

Caregiver adalah seseorang yang memberikan bantuan pada orang yang mengalami ketidakmampuan dan memerlukan bantuan karena penyakit atau keterbatasannya seperti pasangan, anak, menantu, cucu, saudara, tetangga, teman maupun hubungan kekerabatan lainnya (Julianti, 2013). Caregiver memiliki tugas membantu dalam mobilitas, komunikasi, perawatan diri, perubahan emosional dan psikologis sehingga caregiver harus menyeimbangkan peran tanggung jawab ganda merawat pasien stroke serta menyesuaikan gaya hidupnya. Semakin lemah dan kronis penyakit pasien maka semakin tinggi beban yang dialami caregiver (Gbiri, Olawale, \& Isaac, 2015). 
Beban caregiver adalah tekanan yang muncul pada caregiver saat melakukan perawatan pada pasien stroke. Beban tersebut dapat berupa beban fisik, psikologis, sosial, dan keuangan (Rha, et al., 2015). Dampak dari beban yang berpengaruh pada kondisi kesehatan caregiver meliputi kelelahan, gangguan tidur, tidak nafsu makan, sakit kepala, tekanan darah tinggi, maag. Beban caregiver juga berpengaruh pada kondisi emosi meliputi stres, gelisah dan khawatir dengan kondisi pasien (Pratiwi, 2018).

Asniar, Sahar, dan Wiarsih (2010) menunjukkan bahwa keluarga memiliki beban tinggi dalam merawat yaitu beban psikologis yang diidentifikasi melalui karakteristik verbal seperti stress, menangis dan juga rasa bersalah, serta perubahan emosi pasien yang sering marah dan berperilaku buruk dan beban fisik dapat dilihat dari ekspresi dan ungkapan rasa lelah, jenuh dan capek. Beberapa faktor yang mempengaruhi beban caregiver menurut Joanna Briggs Institute (2012) dan Sari (2017) antara lain usia, jenis kelamin, penghasilan, tingkat pendidikan, status pekerjaan, status pernikahan, hubungan keluarga dan dukungan keluarga.

Perbedaan penelitian ini dengan penelitian sebelumnya yaitu penelitian ini meneliti beban caregiver merawat pasien stroke, sedangkan penelitian lain dengan penyakit lain berfokus pada pasien dengan masalah kesehatan lain seperti kanker stadium lanjut, anak autis, RPK dan lansia. Alat pengukuran beban pada penelitian menggunakan Zarit Burden Interview sedangkan penelitian lain dengan Caregiver Reaction Assesment. Penelitian ini menjelaskan delapan faktor yang berhubungan dengan beban caregiver meliputi: usia, jenis kelamin, pendidikan, pekerjaan, penghasilan, status pernikahan, hubungan keluarga dan dukungan keluarga sedangkan penelitian lain faktor tersebut hanya digunakan pada data karakteristik responden saja.

\section{METODE}

Jenis penelitian ini adalah penelitian kuantitatif dengan menggunakan desain penelitian cross sectional. Jumlah sampel sebanyak 56 caregiver dengan menggunakan rumus Slovin. Teknik pengambilan sampel menggunakan purposive sampling. Kriteria inkluasi pada penelitian ini adalah caregiver berusia $\geq 26$ tahun, responden merupakan caregiver utama yang merawat pasien stroke, minimal merawat 3 bulan. Penelitian dilaksanakan pada tanggal 22-31 Mei 2019. Kriteria eksklusi pada penelitian ini adalah caregiver yang mengalami sakit ketika dilakukan penelitian. Instrumen penelitian menggunakan kuesioner Zarit Burden Interview. Analisis data statistik menggunakan Chi Square. Tempat penelitian di rawat jalan RSUD Tugurejo Semarang. Sebelum penelitian dilaksanakan peneliti mengajukan uji etik kepada tempat penelitian dan setelah itu peneliti diberikan surat keterangan lolos uji etik.

\section{HASIL}

Tabel 1. Distribusi usia, jenis kelamin, Distribusi usia, jenis kelamin, pendidikan, pekerjaan, penghasilan, status pernikahan, hubungan keluarga, dukungan keluarga, beban caregiver.

\begin{tabular}{clcc}
\hline No & \multicolumn{1}{c}{ Variabel } & F & \% \\
\hline 1. & Usia & 31 & 55,4 \\
& - Dewasa & 25 & 44,6 \\
& - Lansia & & \\
2. & Jenis kelamin & 34 & 60,7 \\
& - Laki-Laki & 22 & 39,3 \\
& - Perempuan & &
\end{tabular}




\begin{tabular}{|c|c|c|c|}
\hline No & Variabel & $F$ & $\%$ \\
\hline \multirow[t]{5}{*}{3.} & Pendidikan & 17 & 30,4 \\
\hline & $-\quad \mathrm{SD}$ & 4 & 7,1 \\
\hline & $-\quad \mathrm{PT}$ & 11 & 19,6 \\
\hline & - SMP & 24 & 42,9 \\
\hline & - $\quad$ SMA & & \\
\hline \multirow[t]{3}{*}{4.} & Status Pekerjaan & & \\
\hline & - Tidak Bekerja & 22 & 39,3 \\
\hline & - Bekerja & 34 & 60,7 \\
\hline \multirow[t]{3}{*}{5.} & Penghasilan & & \\
\hline & - BawahUMR & 29 & 51,8 \\
\hline & - $\quad$ AtasUMR & 27 & 48,2 \\
\hline \multirow[t]{3}{*}{6} & Status Pernikahan & & \\
\hline & - Menikah & 51 & 91,1 \\
\hline & - BelumMenikah & 5 & 8,9 \\
\hline \multirow[t]{3}{*}{7} & Hubungan Keluarga & & \\
\hline & - Pasangan & 26 & 46,4 \\
\hline & - Anak & 30 & 53,6 \\
\hline \multirow[t]{4}{*}{8} & Dukungan Keluarga & & \\
\hline & - Rendah & 6 & 10,7 \\
\hline & - $\quad$ Sedang & 19 & 33,9 \\
\hline & - Tinggi & 31 & 55,4 \\
\hline \multirow[t]{5}{*}{9} & Beban Keluarga & & \\
\hline & - Tidak adabeban & 14 & 25,0 \\
\hline & - Ringan & 16 & 28,6 \\
\hline & - Sedang & 13 & 23,2 \\
\hline & - Berat & 13 & 23,2 \\
\hline
\end{tabular}

\section{PEMBAHASAN}

\section{Hubungan Usia dengan Beban Caregiver}

Hasil penelitian menunjukan bahwa usia caregiver yang merawat pasien stroke paling banyak adalah usia dewasa (26-45 tahun) sebanyak 55,4\%. Hal ini didukung oleh hasil penelitian Putri (2013) yang mengatakan bahwa rata-rata usia caregiver yaitu 40,78 tahun, dimana usia tersebut termasuk dalam usia dewasa. Seseorang dapat dikatakan dewasa apabila telah memiliki kekuatan bereproduksi, dan memiliki kesiapan kognitif, afektif, dan psikomotor, serta dapat diharapkan memainkan peranannya bersama dengan individu-individu lain dalam masyarakat.

Pada usia dewasa masing-masing individu sudah mulai mengabaikan keinginan atau hak-hak pribadinya, kebutuhan atau kepentingan yang utama adalah keluarga sehingga caregiver lebih banyak ditemukan diusia ini (Hartati, 2012). Selain itu, caregiver yang berusia dewasa dianggap cukup matang dalam pengalaman hidup, bijaksana dalam mengambil keputusan, mampu berpikir rasional, mampu mengendalikan emosi dan semakin toleran terhadap orang lain (Nuraenah, Mustikasari, \& Putri, 2014).

Hasil penelitian menunjukkan caregiver lansia sebanyak 44,0\% memiliki beban berat. Usia berhubungan secara signifikan dengan beban caregiver dalam merawat anggota keluarga yang mengalami stroke, dibuktikan dengan nilai $p$ value 0,009. Hasil penelitian ini didukung oleh penelitian lain yang dilakukan oleh Sari (2017) yang membuktikan bahwa adanya hubungan antara usia dengan beban caregiver dengan nilai $p$ value 0,015. Semakin tua usia caregiver maka beban yang dirasakan akan semakin tinggi, hal ini disebabkan karena adanya penurunan fisik yang dialami oleh caregiver yang berusia lanjut usia, sehingga kemampuan untuk dapat merawat seseorang dengan kecacatan fungsional juga akan menjadi berkurang (Adianta \& Wardianti, 2018, II12). Selain itu, caregiver yang sudah memasuki usia lansia mulai khawatir tentang siapa yang akan mengurus keluarganya nanti di masa yang akan datang (Aruan \& Sari, 2018).

\section{Hubungan Jenis Kelamin dengan Beban Caregiver}

Hasil penelitian menunjukan bahwa mayoritas caregiver yang merawat anggota keluarga stroke adalah perempuan $60,7 \%$. Sesuai dengan penelitian yang dilakukan oleh Hartati (2012) yang mengatakan bahwa mayoritas caregiver yang merawat pasien stroke adalah perempuan yaitu 
Tabel 2. Distribusi Proporsi

Beban Caregiver

\begin{tabular}{|c|c|c|c|c|c|c|c|c|c|c|}
\hline & & \multicolumn{2}{|c|}{$\begin{array}{l}\text { Tidak Ada } \\
\text { Beban }\end{array}$} & \multicolumn{2}{|c|}{$\begin{array}{l}\text { Beban } \\
\text { Ringan }\end{array}$} & \multicolumn{2}{|c|}{$\begin{array}{l}\text { Beban } \\
\text { Sedang }\end{array}$} & \multicolumn{2}{|c|}{$\begin{array}{l}\text { Beban } \\
\text { Berat }\end{array}$} & \multirow[t]{2}{*}{$\mathrm{P}$} \\
\hline & & $\mathrm{F}$ & $\%$ & $\mathrm{~F}$ & $\%$ & $\mathrm{~F}$ & $\%$ & $\mathrm{f}$ & $\%$ & \\
\hline \multirow{2}{*}{ Usia } & Dewasa & 0 & 200 & 10 & 323 & 10 & 323 & 2 & 65 & 0000 \\
\hline & Lansia & 5 & 200 & 6 & 240 & 30 & $\begin{array}{l}52,3 \\
120\end{array}$ & 11 & 40 & 0,009 \\
\hline \multirow{3}{*}{$\begin{array}{l}\text { Jenis } \\
\text { Kelamin }\end{array}$} & & & & & & & & & & \\
\hline & Laki-laki & 9 & 40,9 & 10 & 45,5 & 0 & 0 & 3 & 13,6 & 0,001 \\
\hline & Permpuan & 5 & 14,7 & 6 & 17,6 & 13 & 38,2 & 10 & 29,4 & \\
\hline \multirow{2}{*}{ Pendidikan } & SD+SMP & 5 & 17,9 & 7 & 25,0 & 6 & 21,4 & 10 & 35,7 & 0,155 \\
\hline & $\mathrm{SMA}+\mathrm{PT}$ & 9 & 32,1 & 9 & 32,1 & 7 & 25,0 & 3 & 10,7 & \\
\hline \multicolumn{11}{|l|}{ Pekerjaan } \\
\hline & Tidak Bekerja & 1 & 4,5 & 5 & 22,7 & 6 & 27,3 & 10 & 45,5 & \\
\hline & Bekerja & 13 & 38,2 & 11 & 32,4 & 7 & 20,6 & 3 & 8,8 & 0,002 \\
\hline \multirow{2}{*}{ Penghasilan } & Bawah UMR & 2 & 6,9 & 6 & 20,7 & 8 & 27,6 & 13 & 44,8 & 0,000 \\
\hline & Atas UMR & 12 & 44,4 & 10 & 37,0 & 5 & 18,5 & 0 & 0 & \\
\hline \multicolumn{11}{|l|}{ Pernikahan } \\
\hline & Menikah & 10 & 19,6 & 15 & 29,4 & 13 & 25,5 & 13 & 25,5 & 0,025 \\
\hline & $\begin{array}{l}\text { Belum } \\
\text { Menikah }\end{array}$ & 4 & 80,0 & 1 & 20,0 & 0 & 0 & 0 & 0 & \\
\hline \multicolumn{11}{|l|}{ Hubungan } \\
\hline Keluarga & Pasangan & 5 & 19,2 & 7 & 26,9 & 3 & 11,5 & 11 & 42,3 & 0,011 \\
\hline & Anak & 9 & 30,0 & 9 & 30,0 & 10 & 33,3 & 2 & 6,7 & \\
\hline \multicolumn{11}{|l|}{ Dukungan } \\
\hline Keluarga & $\begin{array}{l}\text { Rendah + } \\
\text { Sedang }\end{array}$ & 2 & 8,0 & 2 & 8,0 & 8 & 32,0 & 13 & 52,0 & \\
\hline & Tinggi & 12 & 38,7 & 14 & 45,2 & 5 & 16,1 & 0 & 0 & 0,000 \\
\hline
\end{tabular}

sebanyak $79,5 \%$. Hal ini dapat dikarenakan oleh berbagai macam faktor, salah satunya adalah norma dan budaya yang berlaku didalam masyarakat Indonesia. Di Indonesia peran perempuan adalah mengurus rumah tangga, seperti memasak, mencuci, membersihkan rumah, melayani suami, dan merawat anggota keluarga, sedangkan peran laki- laki adalah mencarinafkah sehingga dalam hal ini perempuan lebih banyak berperan dalam merawat keluarganya yang sakit (Utami, 2013).

Caregiver perempuan memiliki beban sedang sebanyak 38,2\% dan beban berat sebanyak 29,4\%. Berdasarkan hasil uji statistik diperoleh nilai $p$ value 0,001 . Hasil penelitian ini sejalan dengan Patricia (2015) dengan $p$ value 0,032 bahwa terdapat hubungan antara jenis kelamin dengan beban caregiver. Caregiver perempuan memiliki beban yang lebih 
tinggi dibandingkan dengan caregiver lakilaki, hal ini disebabkan karena perempuan dalam menentukan sifatnya lebih didasarkan pada penghayatan dibanding pengetahuan terhadap objek tertentu sehingga perempuan lebih mudah mengalami frustasi dan beban ketika terjadi masalah (Adianta \& Wardianti, 2018). Beban caregiver juga dapat dipengaruhi oleh peran sosial dan hormonal. Pada peran sosial, perempuan merupakan caregiver utama dan paling dominan dibandingkan laki-laki. Pada peran hormonal, hormon oksitosin memberikan pengaruh dalam distress. Saat merawat pasien stroke, perempuan akan mengalami stress karena saat hormon oksitosin harusnya dapat meningkat namun secara bersamaan caregiver harus menyalurkan perhatiannya terhadap pasien stroke (Rafiyah \& Suttharangsee, 2011). Pada penelitian ini 13,6\% responden lakilaki mengalami beban berat. Hal ini disebabkan merawat anggota keluarga tidak sejalan dengan tugasnya mencari nafkah. selain itu, caregiver laki-laki juga kurang ahli dalam perawatan (Nuraenah, Mustikasari, \& Putri, 2014).

\section{Hubungan Pendidikan dengan Beban Caregiver}

Hasil penelitian menunjukkan mayoritas pendidikan responden adalah SMA yaitu sebanyak 42,9\%. Tingkat pendidikan menentukan seseorang untuk memiliki pengetahuan yang lebih luas, kemampuan dan keterampilan serta ketika petugas kesehatan menyampaikan pendidikan kesehatan terkait masalah kesehatan pasien, keluarga dapat memahami informasi yang diberikan yang nantinya bermanfaat untuk perawatan (Zahra, 2016).

Caregiver dengan pendidikan rendah seperti SD dan SMP mayoritas mengalami beban berat sebanyak $35,7 \%$. Penelitian ini didukung oleh penelitian Adianta dan Wardianti (2018) yang menemukan bahwa caregiver dengan tingkat pendidikan SD cenderung mengalami beban berat lebih banyak yaitu sejumlah 28 responden $(27,5 \%)$, sedangkan pada pendidikan SMA mayoritas mengalami beban sedang yaitu sebanyak 18 responden $(17,6 \%)$. Hal ini dapat diartikan bahwa tingkat pendidikan yang tinggi menandakan adanya beban yang semakin ringan. Sebaliknya tingkat pendidikan yang rendah memiliki beban yang lebih tinggi. Tingkat pendidikan keluarga yang terkategori tinggi berhubungan dengan kemampuan pengetahuan dalam menggunakan dan memilih fasilitas kesehatan yang tepat dalam mengobati dan merawat pasien stroke sehingga bisa mengurangi beban caregiver karena lebih cepat dan tepat dalam mendapatkan bantuan dari petugas kesehatan (Suwadirman, 2011).

Semakin tinggi pendidikan seseorang semakin mudah pula menerima informasi dan pada akhirnya pengetahuan yang dimilikinya semakin banyak. Seseorang dengan pengetahuan yang tinggi cenderung memiliki persepsi positif terkait merawat anggota keluarga yang sakit, berbeda dengan pengetahuan yang rendah caregiver akan merasakan distres emosional terkait kurangnya pengetahuan dan ketidakpahaman terkait masalah yang dihadapi (Erwina, Gusty \& Monalisa, 2016).

Hasil Uji statistik menunjukkan nilai $p$ value 0,155 yang berarti tidak ada hubungan antara status pendidikan dengan beban caregiver dalam merawat anggota keluarga stroke, hanya saja tingkat pendidikan yang lebih tinggi akan menghasilkan gaji semakin tinggi. Gaji yang tinggi akan mengurangi masalah keuangan terkait penyediaan perawatan. Penelitian ini sejalan dengan penelitian Nurjannah dan Setyopranoto (2018) 
dengan nilai $p$ value 0,1000 bahwa pendidikan tidak berhubungan dengan beban caregiver dalam merawat pasien stroke. Walaupun hubungan ini tidak bermakna secara statistik tetapi beban caregiver berpendidikan rendah 1,35 kali lebih besar dibanding prevalensi caregiver pendidikan tinggi.

\section{Hubungan Pekerjaan dengan Beban Caregiver}

Hasil penelitian menunjukkan bahwa mayoritas caregiver berdasarkan pekerjaannya adalah bekerja yaitu sebanyak $60,7 \%$. Sesuai dengan penelitian yang dilakukan oleh Putri (2013) sebanyak $60,1 \%$ caregiver berstatus bekerja. Hal ini disebabkan karena caregiver mempunyai tanggung jawab untuk membiayai keluarganya khususnya dalam pemenuhan kebutuhan sehari-hari dan kebutuhan akan pelayanan kesehatan.

Caregiver yang berstatus tidak bekerja memiliki beban yang berat sebanyak 45,5\%, sedangkan caregiver yang bekerja diketahui tidak ada beban sebanyak $38,2 \%$. Penelitian ini didukung Puspitasari (2017) yang menyatakan bahwa caregiver yang bekerja diketahui memiliki beban sedikit atau tidak ada beban sebanyak $50 \%$, sementara caregiver yang tidak bekerja memiliki beban ringan sampai sedang sebanyak 45,5\% dan beban berat sebanyak 4,5\%. Pekerjaan merupakan kegiatan yang menyita waktu sehingga pekerjaan mempunyai pengaruh terhadap keluarga dalam memberikan perawatan (Wawan \& Dewi, 2011). Caregiver yang tidak bekerja cenderung memiliki beban ekonomi yang besar dan merasa kegiatannya dalam merawat pasien terasa membosankan, selain itu caregiver yang tidak bekerja akan memiliki kehidupan sosial yang terbatas dan memiliki anggapan peran yang berbeda dalam proses perawatan sehingga beban yang dirasakan akan meningkat (Aruan \& Sari, 2018). Berbeda dengan caregiver yang bekerja mereka memiliki kegiatan pengalihan disamping merawat pasien dan tentunya akan mendapatkan penghasilan sehingga akan mengurangi beban ekonomi dalam merawat anggota keluarga stroke. Hasil uji statistik diperoleh nilai $p$ value 0,002 yang berarti ada hubungan antara status pekerjaan dengan beban caregiver dalam merawat anggota keluarga stroke.

\section{Hubungan Penghasilan dengan Beban Caregiver}

Hasil penelitian menunjukkan bahwa penghasilan caregiver pada pasien stroke mayoritas di bawah Upah Minimum Regional (UMR) Kota Semarang 2019 (Rp2.498.000) sebanyak 51,8\%. Caregiver yang memiliki penghasilan di bawah UMR sebanyak $44,8 \%$ memiliki beban berat. Pendapatan yang rendah dapat mengakibatkan beban yang tinggi dalam hal finansial pada caregiver. Hasil penelitian ini sesuai penelitian Erwanto (2016) dengan nilai $p$ value 0,000 bahwa caregiver dengan pendapatan atas UMR $(80,0 \%)$ mayoritas tidak memiliki beban, sedangkan caregiver dengan pendapatan di bawah UMR $(77,4 \%)$ memiliki beban dalam merawat.

Semakin rendah penghasilan seseorang dapat mempengaruhi seseorang untuk memperoleh informasi tentang status kesehatan dan keterbatasan biaya menjangkau fasilitas kesehatan di masyarakat baik media informasi ataupun pusat pelayanan kesehatan (Zahra, 2016). Panjang masa pengobatan, beratnya suatu penyakit, dan harga obat yang mahal dapat menjadi faktor untuk munculnya beban finansial pada caregiver (Darwin, Hadisukanto \& Elvira, 2013). Pada hasil uji statistik diperoleh $p$ value 0,000 yang 
berarti ada hubungan antara penghasilan dengan beban caregiver dalam merawat anggota keluarga stroke.

\section{Hubungan Status Pernikahan dengan Beban Caregiver}

Hasil penelitian mengenai status pernikahan mayoritas responden sudah menikah yaitu sebanyak 91,1\%. Hal ini sesuai dengan hasil penelitian yang dilakukan oleh Purdani (2016) bahwa $100 \%$ caregiver pasien stroke adalah berstatus menikah. Caregiver yang berstatus menikah memiliki beban berat sebanyak 25,5\%, sedangkan pada caregiver yang belum menikah sebanyak $80 \%$ yang tidak memiliki beban.

Hasil uji statistik diperoleh $p$ value 0,025 yang berarti bahwa ada hubungan antara status pernikahan dengan beban caregiver dalam merawat anggota keluarga stroke. Caregiver yang berstatus menikah memiliki tanggung jawab ganda yaitu mengurus rumah tangga dan merawat anggota keluarga yang sakit. Hal ini tentu saja menimbulkan beban yang sangat berat bagi caregiver karena berusaha untuk melaksanakan tugas itu semua secara optimal. Selain itu, hubungan pernikahan yang tidak harmonis ataupun masalah dalam hubungan pernikahan dapat menyebabkan stres pada caregiver (Erwina, Gustya \& Monalisa, 2016).

\section{Hubungan Keluarga dengan Beban Caregiver}

Hubungan caregiver dengan pasien stroke mayoritas adalah sebagai anak sebanyak 53,6\%. Penelitian ini sejalan dengan pnelitian yang dilakukan oleh Putra (2017) yang menunjukkan bahwa 63,5\% adalah hubungan antara orangtua dan anak. Banyaknya jumlah caregiver yang memiliki hubungan sebagai anak dapat dipengaruhi oleh berbagai faktor, salah satunya adalah hukum adat, norma dan kepercayaan yang berlaku di masyarakat bahwa anak harus berbakti kepada orang tuanya. Selain itu, berkaitan pula dengan adanya fungsi utama keluarga dalam perawatan kesehatan yaitu untuk mempertahankan keadaan kesehatan anggota keluarga agar tetap memiliki produktivitas tinggi meliputi mengenal kesehatan keluarga, memutuskan tindakan kesehatan yang tepat bagi keluarga, merawat keluarga yang mengalami gangguan kesehatan, memodifikasi lingkungan keluarga untuk menjamin kesehatan dan memanfaatkan fasilitas pelayanan kesehatan (Hartati, 2012).

Beban berat dirasakan oleh caregiver sebagai pasangan pasien stroke yaitu sebanyak 42,3\%. Hasil uji statistik didapatkan nilai $p$ value 0,011. Hasil penelitian ini sesuai dengan penelitian yang dilakukan oleh Patricia (2015) bahwa terdapat hubungan antara hubungan caregiver-pasien dengan beban caregiver dengan nilai $p$ value 0,000 . Beban caregiver akan dirasakan lebih berat pada individu yang mempunyai hubungan langsung dengan pasien. Hubungan sebagai pasangan (suami/istri) dalam suatu perkawinan salah satunya ditandai oleh adanya saling ketergantungan dari masingmasing pasangannya, adanya sikap dan kondisi emosional yang negatif dalam perkawinan dapat mempengaruhi beban dalam perawatan pasien (Putri, Konginan, \& Mardiana, 2013).

\section{Hubungan Dukungan Keluarga dengan Beban Caregiver}

Hasil penelitian menunjukkan bahwa mayoritas caregiver memiliki dukungan keluarga yang tinggi sebanyak 55,4\%. Dukungan keluarga adalah bentuk perilaku melayani yang dilakukan oleh keluarga, baik dalam dukungan emosional (perhatian, kasih sayang, empati), 
dukungan penghargaan (menghargai dan upan balik), dukungan informasi (saran, nasihan, informasi) dan dukungan instrumental (bantuan tenaga, dana dan waktu).

Adanya dukungan orang-orang sekitar menjadikan caregiver lebih kuat, sehingga mampu dalam menjalani perannya. Dukungan sosial dalam keluarga sangat diperlukan oleh caregiver agar dapat menjalankan aktivitasnya secara maksimal dengan meminimalisir potensi stress yang muncul saat perawatan Caregiver yang memiliki dukungan keluarga yang rendah mayoritas mengalami beban yang berat sebanyak $52,0 \%$. Hasil uji statistik diperoleh $p$ value 0,000 yang berarti ada hubungan antara kedua variabel. Penelitian ini sejalan dengan penelitian Khatimah (2018) yang menunjukkan adanya hubungan signifikan antara dukungan keluarga dengan beban yang dialami caregiver, dan didapatkan nilai $\mathrm{r}=-0,33$ menunjukkan hubungan korelasi negatif antara kedua variabel yang menunjukan semakin tinggi dukungan keluarga yang diterima maka semakin rendah beban yang dirasakan caregiver stroke. Sebaliknya semakin rendah dukungan keluarga yang diterima maka semakin tinggi beban yang akan dirasakan.

Caregiver yang memiliki dukungan keluarga yang tinggi akan menjadikan caregiver optimis dalam menghadapi kehidupan saat ini maupun masa yang akan datang lebih trampil dalam memenuhi kebutuhan psikologis dan tingkat kecemasan yang rendah, memiliki kemampuan untuk mencapai apa yang diinginkan (Nugraha, 2011).

\section{KESIMPULAN}

Penelitian ini menunjukkan bahwa usia, jenis kelamin, pendidikan, status pekerjaan, penghasilan, status pernikahan, hubungan keluarga, dan dukungan keluarga berhubungan secara signifikan dengan beban caregiver dalam merawat anggota keluarga yang mengalami stroke.

\section{SARAN}

\section{Bagi Institusi Pendidikan}

Institusi pendidikan dapat menjadikan penelitian ini sebagai referensi untuk mencetak calon perawat dengan kompetensi pengelolaan pasien stroke yang tidak berfokus kepada klien stroke saja tetapi juga kepada caregiver.

\section{Bagi Pelayanan Kesehatan}

Penelitian ini dapat memotivasi pelayanan kesehatan untuk membuat Standar Prosedur Operasional (SPO) mengenai jenis intervensi yang dapat digunakan untuk menurunkan beban caregiver dalam merawat anggota keluarga yang mengalami stroke. Pelayanan kesehatan juga diharapkan melibatkan caregiver secara optimal dalam memberikan informasi terkait perawatan pasien stroke sehingga dapat mengurangi beban caregiver.

\section{Bagi Penelitian Selanjutnya}

Peneliti selanjutnya disarankan untuk melakukan penelitian secara spesifik pada variabel beban caregiver dalam merawat anggota keluarga yang mengalami stroke.

\section{DAFTAR PUSTAKA}

Adianta, I. K. A., \& Wardianti, G. A. (2018). Beban keluarga pada penderita diabetes. Jurnal Riset Keperawatan, 2(1), 85-90.

American Heart Association. (2010). American Heart Association Public Policy Agenda, 2010-2014. Diperoleh dari http://www.heart.org/idc/groups/heart 
public/@wcm/@adv/documents/down loadable/ucm_301674.pdf

Aruan, T. N. R., \& Sari, S. P. (2018). Gambaran beban ibu sebagai caregiver anak dengan skizofrenia di poliklinik rawat jalan rumah sakit jiwa. Diperoleh dari http://eprints.undip.ac.id/63015/

Asniar, A., Sahar, J., \& Wiarsih, W. (2010). Studi fenomenologi tentang pengalaman keluarga merawat anggota keluarga paska stroke di rumah. Jurnal Ners Indonesia, 1(1), 54-61. doi: 10.31258/jni.1.1.54-61

Darwin, P., Hadisukanto, G., \& Elvira, S. D. (2013). Beban perawatan dan ekspresi emosi pada pramurawat pasien skizofrenia di rumah sakit jiwa. Journal Indonesia Medical Association 63 (2), 46-51.

Erwanto, R. (2016). Faktor yang berhubungan dengan beban keluarga dalam merawat aktifitas sehari-hari pada Lansia. Jurnal Ners dan Kebidanan Indonesia, 4(3), 117-122.

Erwina, I., Gusty, R. P., \& Monalisa. (2016). Distress emosional pada caregiver perempuan dengan anggota keluarga yang mengalami gangguan jiwa. Ners Jurnal Keperawatan, 12(1), 28-37. doi: 10.25077/njk.12.1.2837.2016

Friedman, M. M., Bowden, O., \& Jones, M. (2010). Keperawatan keluarga: riset, teori, \& praktik. (5th ed.). Jakarta: EGC.

Gbiri, C. A., Olawale, O. A., \& Isaac, S.O (2015). Stroke management: Informal caregivers' burdens and strians of caring for stroke survivors. Annals of
Physical and Rehabilitation Medicine, 58(2), 98-103. doi: 10.1016/j.rehab.2014.09.017

Hartati, J. (2012). Hubungan tingkat pengetahuan dengan perilaku family caregiver dalam merawat penderita paska Stroke di Rumah Tahun 2012. Universitas Islam Negeri Syarif Hiddayatullah, Jakarta. Diperoleh dari http://repository.uinjkt.ac.id/dspace/ha ndle/123456789/25560

Joanna Briggs Institute. (2012). Caregiver burden of terminally-ill adults in the home setting. Nursing and Health Science, 14(4), 435-437. doi: $10.1111 /$ nhs. 12013

Julianti, E. (2013). Pengalaman caregiver dalam merawat pasien pasca stroke di rumah pada wilayah kerja Puskesmas Benda Baru Kota Tangerang Selatan. Universitas Islam Negeri Syarif Hiddayatullah, Jakarta. Diperoleh dari http://repository.uinjkt.ac.id/dspace/ha ndle/123456789/25548

Kementerian Kesehatan Republik Indonesia (2018). Hasil utama Riskesdas 2018. Diperoleh dari https://www.kemkes.go.id/resources/d ownload/info-terkini/hasil-riskesdas2018.pdf

Khatimah, H. (2018). Hubungan antara dukungan deluarga dengan caregiver burden pada family caregiver pasien stroke. Universitas Islam Indonesia, Yogyakarta. Diperoleh dari https://dspace.uii.ac.id/handle/123456 789/12708

Muttaqin, A. (2011). Asuhan keperawatan pada klien dengan gangguan sistem persarafan. Jakarta: Salemba Medika. 
Nugraha, N. J. (2011). Pengalaman keluarga dalam merawat anggota keluarga yang menjalani terapi hemodialisa di Kota Bandung: Studi fenomenologi. Universitas Indonesia, Depok. Diperoleh dari http://lib.ui.ac.id/file?file=digital/2028 $1884-$

T\%20Nandang\%20Jamiat\%20Nugrah a.pdf

Nuraenah, Mustikasari, \& Putri, S. S. E. (2014). Hubungan dukungan keluarga dan beban keluarga dalam merawat anggota dengan riwayat perilaku kekerasan di RS Jiwa Islam. Jurnal Keperawatan Jiwa, 2(1), 41-50. doi: 10.26714/jkj.2.1.2014.41-50

Nurjannah, S., \& Setyopranoto (2018). Determinan beban pengasuh pasien stroke pasca perawatan di rumah sakit di RSUD dr. Soediran Mangun Sumarso, Wonogiri. Berita Kedokteran Masyarakat, 34(3), 143148. doi: $10.22146 / \mathrm{bkm} .33850$

Patricia, H. (2015). Hubungan beban dengan kualitas hidup pada caregiver klien skizofrenia yang berkunjung ke instalasi rawat jalan Rumah Sakit Jiwa Tampan Pekanbaru. Universitas Andalas, Padang. Diperoleh dari http://scholar.unand.ac.id/id/eprint/117 2

Pratiwi, J. N. (2018). Rancangan intervensi psikologis untuk mengurangi beban perawatan pada para perawat Lansia. Universitas Muhammadiyah Surakarta. Diperoleh dari http://eprints.ums.ac.id/67129/

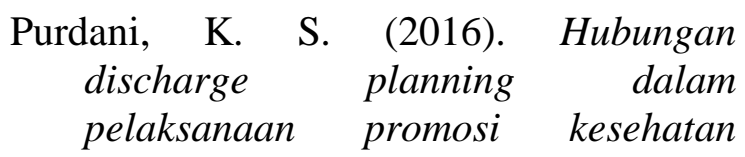

rumah sakit (PKRS) RSUD Tugurejo Semarang dengan beban caregiver insan pasca stroke di Semarang. Universitas Diponegoro, Semarang. Diperoleh dari http://eprints.undip.ac.id/51141/2/TES IS.pdf

Puspitasari, S. (2017). Gambaran beban caregiver keluarga pada pasien kanker di rumah singgah yayasan kanker. Universitas Islam Negeri Syarif Hidayatullah, Jakarta. Diperoleh dari

Putra, D. A. (2017). Gambaran strategi koping family caregiver pada Lansia dengan hambatan activities of dalily living di Dusun Pringgading Guwosari Pajangan Bantul Yogyakarta. STIKES Jenderal Achmad Yani, Yogyakarta Diperoleh dari

http://repository.unjaya.ac.id/2264/2/D EDE\%20ADEKAYASA\%20PUTRA_ 2213088_pisah.pdf

Putri, Y. S. E. (2013). Prediktor beban merawat dan tingkat depresi caregiver dalam merawat lanjut usia dengan demensia di masyarakat. Jurnal Ners, 8(1), 88-97.

Putri, D. P., Konginan, A., \& Mardiana, N. (2013). Korelasi social support dengan caregiver burden pada istri pasien penyakit ginjal kronis yang menjalani hemodialisis di RSUD Dr. Soetomo Surabaya. Jurnal Psikiatri Surabaya. 3(1), 59-69.

Rafiyah, I., \& Sutharangsee, W. (2011). Review: Burden on family caregivers caring for patients with schizophrenia and its related factors. Nurse Media 
Journal of Nursing, 1(1), 29-41. doi: 10.1470/nmjn.v1i1.745

Rekam Medis RSUD Tugurejo Provinsi Jawa Tengah. (2019). Prevalensi pasien stroke di rawat jalan tahun 2016-2018. Semarang: RSUD Tugurejo Provinsi Jawa Tengah.

Rha, S. Y., Park, Y., Song, S. K., Lee, C. E., \& Lee, J. (2015). Caregiving burden and the quality of life of family caregivers of cancer patients: The relationship and correlates. European Journal of Oncology Nursing., 19(4), 376-82. doi: 10.1016/j.ejon.2015.01.004

Sari, I. W. W. (2017). Faktor-faktor yang memengaruhi beban family caregiver dalam merawat anggota keluarga yang menderita kanker stadium lanjut. Universitas Gajah Mada, Yogyakarta. Diperoleh dari http://etd.repository.ugm.ac.id/peneliti an/detail/112338

Suwadirman, D. (2011). Hubungan antara dukungan keluarga dengan beban keluarga untuk mengikuti regimen terapeutik pada keluarga klien halusinasi di RSUD Serang.
Universitas Indonesia, Depok. Diperoleh dari http://lib.ui.ac.id/detail.jsp?id=202803 24

Utami, Y. H. (2013). Hubungan antara tingkat kemandirian pasien geriatri dengan beban pramurawat yang merawatnya di RSUPN Dr. Cipto Mangunkusumo Jakarta. Universitas Indonesia, Depok. http://lib.ui.ac.id/file?file=digital/2036 7273-SP-Yusri\%20Hapsari.pdf

Wawan, A., \& Dewi, M. (2011). Teori dan pengukuran pengetahuan sikap dan perilaku manusia. Yogyakarta: Nuha Medika.

Wiwit, S. (2010). Stroke \& penangannya: Memahami, mencegah, \& mengobati stroke. Yogyakarta: Katahati.

Zahra, R. F. (2016). Hubungan dukungan instrumental dengan beban pada anggota keluarga skizofrenia di poli klinik keperawatan jiwa RSJ Grhasia Provinsi DIY. Caring, 8(1), 9-14. Doi: 10.29238/caring.v8i1.362 